\title{
Outcome of Moderate and Severe Traumatic Brain Injury in Hepatitis C Virus Patients
}

\author{
MOHAMMED F. ADEL ALI, M.D.; TAHER M. ALI, M.Sc. and AHMED M. ALI, M.D. \\ The Department of Neurosurgery, Faculty of Medicine, Cairo University
}

\begin{abstract}
Background: TBI (Traumatic Brain Injury) is a worldwide leading cause of death and disability. Liver cirrhosis is known as a significant risk factor for increased morbidity and mortality in trauma patients. HCV (Hepatitis C Virus) is a major cause of liver cirrhosis worldwide especially in Egypt which has the highest HCV prevalence all over the world.

Aim of Study: Evaluate impact of HCV on outcome of moderate and severe TBI patients.

Methods: Prospective cohort study with stratified random sample of 120 patients of moderate and severe TBI admitted in Kasr Al-Ainy hospitals in the period between February 2016 and January 2017. Screening for HCV antibodies with ELISA technique was done to detect $\mathrm{HCV}+$ ve patients. Assessment of case deterioration after admission, resurger, length of ICU (Intensive care unit) stay, ventilator days, mortality and GOS (Glasgow outcome score) was done.

Results: Out of the 120 patients included; 11 patients were $\mathrm{HCV}+\mathrm{ve}$, while 109 patients were found negative for $\mathrm{HCV}$ antibody. Overall mortality was $28 / 120$ patients. Mortality among $\mathrm{HCV}+\mathrm{ve}$ patients was $7 / 11$ patients compared with the HCV -ve patients: $21 / 109$ patients ( $p=0.003)$. Length of

ICU stay in HCV +ve patients: $8.73 \pm 4.78$ days and in HCV -ve patients: $9.39 \pm 9.52$ days $(p=0.422)$. Ventilator days in $\mathrm{HCV}+$ ve patients were $8.69 \pm 4.12$ and in $\mathrm{HCV}$-ve patients: $12.51 \pm 12.31$ days.

Conclusion: TBI in HCV +ve patients is associated with significantly increased mortality rates and lower GOS compared with $\mathrm{HCV}$-ve patients, which agrees with published literature in this subject. Other significant prognostic indicators were age and GCS on admission.
\end{abstract}

Key Words: Traumatic brain injury - Hepatitis C virus - Liver cirrhosis.

\section{Introduction}

TRAUMATIC brain injury (TBI) is a well recognized worldwide public health challenge $[\mathbf{1 , 2 , 3}]$ Updated statistical records for TBI in Egypt are

Correspondence to: Dr. Mohammed F. Adel Ali, The Department of Neurosurgery, Faculty of Medicine, Cairo University unavailable; however, TBI represents a serious public health problem in Egypt with moderate and severe TBI representing $17.2 \%$ of presenting cases $[\mathbf{5 , 6 ]}$. Hepatitis $\mathrm{C}$ virus infection (HCV) represents a major global health challenge as 80 million people allover the world are chronically infected, 3-4 million new infections and 350,000 deaths yearly due to its related complications [6]. Egypt has the highest HCV prevalence allover the world; according to the Egyptian Health Issues Survey (EHIS) done in 2015; 5.3 million people in the age group (1-59 years) are chronically infected with HCV with 40000 deaths every year due to HCV related complications [7]. The combination of trauma and liver cirrhosis has been termed a "deadly duo [8]," with a nearly three-fold increase in hospital mortality [9] and five-fold increase in all-cause morbidity compared to patients with trauma alone [10] It was also found that emergency surgery was associated with significantly higher mortality in LC (liver cirrhosis) patients compared with elective surgeries [11]. Also in a trauma database study, it was found that the risk of in-hospital death after TBI surgery was significantly higher among patients with liver cirrhosis than in those without [11]. Our study aims to evaluate impact of HCV on prognosis of moderate and severe TBI patients in Egypt regarding mortality, length of ICU stay, ventilator requirements and their outcome.

\section{Patients and Methods}

This is a prospective cohort study with stratified random sample of 120 patients, which was designed to evaluate impact of $\mathrm{HCV}$ on outcome of moderate and severe TBI patients in Egypt. Patients who experienced moderate or severe TBI needing hospital admission in Kasr Al-Ainy Hospitals in the period between February 2016 and January 2017 were included in this study. Screening for $\mathrm{HCV}$ antibodies with ELISA( Enzyme-Linked Immuno- 
sorbent Assay) technique was done to detect $\mathrm{HCV}$ +ve patients.

Only moderate and severe traumatic brain injury patients were included. The following data was abstracted and analyzed: Age, gender, mechanism of injury (blunt vs penetrating), admission vital signs, GCS (Glasgow coma scale) in addition to Child-Pugh score, case deterioration after admission, resurgery, length of ICU (Intensive Care Unit) stay, ventilator days, mortality and Glasgow outcome score (GOS).

\section{Statistical analysis:}

Data were coded and entered using the statistical package SPSS (Statistical Package for the Social Sciences) version 24. Data was summarized using mean, standard deviation, median, minimum and maximum in quantitative data and using frequency (count) and relative frequency (percentage) for categorical data. Comparisons between quantitative variables were done using the non-parametric Mann-Whitney test [12]. For comparing categorical data, Chi square $\left(\chi^{2}\right)$ test was performed. Exact test was used instead when the expected frequency is less than 5 [13]. Multivariate linear regression analysis was done to detect relation between ICU stay duration and HCV adjusting for confounders [12]. Multivariate logistic regression was done to detect if $\mathrm{HCV}$ act as independent predictor of bad outcome after adjusting for confounders [13]. $p$ values less than 0.05 were considered as statistically significant.

\section{Results}

This study included 120 moderate and severe head trauma patients admitted to Cairo University Hospitals during the period between February 2016 and January 2017. 11 patients $(9.2 \%)$ were HCV +ve while 109 patients $(90.8 \%)$ were found negative for $\mathrm{HCV}$ antibody. Among the 120 patients: 112 were males $(93.3 \%)$ and 8 were females $(6.7 \%)$. Out of the 112 males, $11(9.8 \%)$ were found HCV +ve and $101(90.2 \%)$ were found HCV -ve. All females included in the study were found HCV -ve (Table 1). Overall age ranged from 1 to 70 years with the mean age of $29.28 \pm 16.13$ years. Mean age was significantly higher among the HCV +ve patients $(49.73 \pm 12.11)$ than among the HCV - ve patients $(27.21 \pm 15.04)(p<0.001)$. Fig. (1) Table (2). Among the HCV +ve patients; 5 were Child A (45.5\%) and 6 were Child B (54.5\%) acoording to Child-Pugh score.

In our study; 72 (60\%) patients suffered from moderate TBI while $48(40 \%)$ patients suffered from severe TBI with overall median GCS of 8 .
Of the HCV +ve group; 4 (36.4\%) had moderate TBI and 7(63.4\%) had severe TBI, while of the HCV ve group; $68(62.4 \%)$ had moderate TBI and 41 (37.6\%) had severe TBI. Table (3) Fig. (2).

Outcome assessment: Of all 120 TBI patients, 30 patients $(25 \%)$ deteriorated after admission while 90 patients (75\%) did not. Of all 120 TBI patients, 5 patients $(4.2 \%)$ had resurgery, while 115 patients $(95.8 \%)$ didn't. Mean length of ICU stay in our 120 studied patients was found to be $9.3 \pm 9.18$ days, ranging from 2 to 42 days. Table (4).

Of all 120 TBI patients, 52 patients $(43.3 \%)$ required ventilation while 68 patients $(56.7 \%)$ didn't. Ventilator days ranged from 1 to 42 days with mean duration of $13 \pm 12.11$ days. Table (5) We had mortality in 28 patients (23.3\%).

Comparison between the outcome of $\mathrm{HCV}+\mathrm{ve}$ and $H C V-v e$ patients:

Tables $(6,7)$ show the differences between $\mathrm{HCV}$ +ve and HCV-ve patients. As shown, there was no significant difference between the two groups regarding case deterioration after admission $(p=0.140)$, resurgery $(p=0.387)$ and ventilator requirements. However, there was significant difference between the two groups regarding mortality $(p=0.003)$ as we found that among the HCV +ve group; $7 / 11$ patients $(63 \%)$ had mortality while among the HCV -ve group; only $21 / 109$ patients (19.3\%) had mortality Fig. (3).

$\mathrm{HCV}+\mathrm{ve}$ patients showed significantly lower GOS than HCV -ve patients as we found that the mean GOS was $2.36 \pm 1.91$ in the former and 3.84 \pm 1.59 in the latter group ( $p=0.012$ ) Fig. (4).

Table (1): Gender distribution and HCV +ve of patients.

\begin{tabular}{llll}
\hline Sex & No. & $\%$ & HCV +ve \\
\hline Male & 112 & 93.3 & $11(9.8 \%)$ \\
Female & 8 & 6.7 & $0(0 \%)$ \\
\hline
\end{tabular}

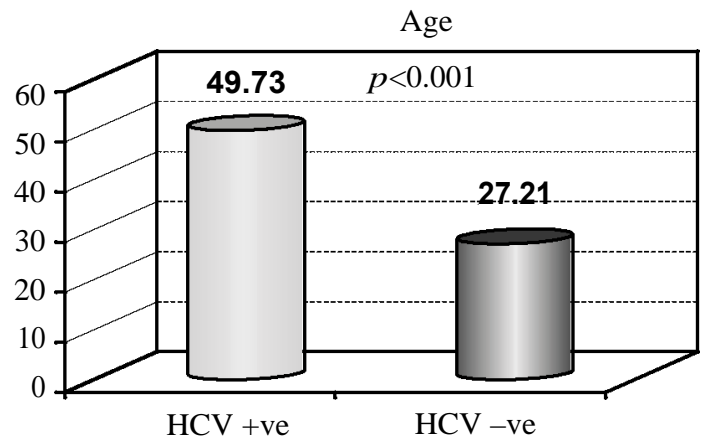

Fig. (1): Mean age among HCV +ve (blue bar) and HCV -ve patients (red bar). 
Table (2): Distribution of studied patients according to age.

\begin{tabular}{cccccc}
\hline & Mean & $\begin{array}{c}\text { Standard } \\
\text { deviation }\end{array}$ & Median & Minimum & Maximum \\
\hline Age & 29.28 & 16.13 & 26.00 & 1.00 & 70.00 \\
\hline
\end{tabular}

Table (3): Distribution of cases according to trauma severity.

\begin{tabular}{|c|c|c|c|c|c|}
\hline & \multicolumn{2}{|c|}{$\mathrm{HCV}+\mathrm{ve}$} & \multicolumn{2}{|c|}{$\mathrm{HCV}-\mathrm{ve}$} & \multirow{2}{*}{$\begin{array}{c}p- \\
\text { value }\end{array}$} \\
\hline & Count & $\%$ & Count & $\%$ & \\
\hline \multicolumn{6}{|l|}{ TBI: } \\
\hline Severe TBI & 7 & 63.6 & 41 & 37.6 & 0.114 \\
\hline Moderate TBI & 4 & 36.4 & 68 & 62.4 & \\
\hline
\end{tabular}

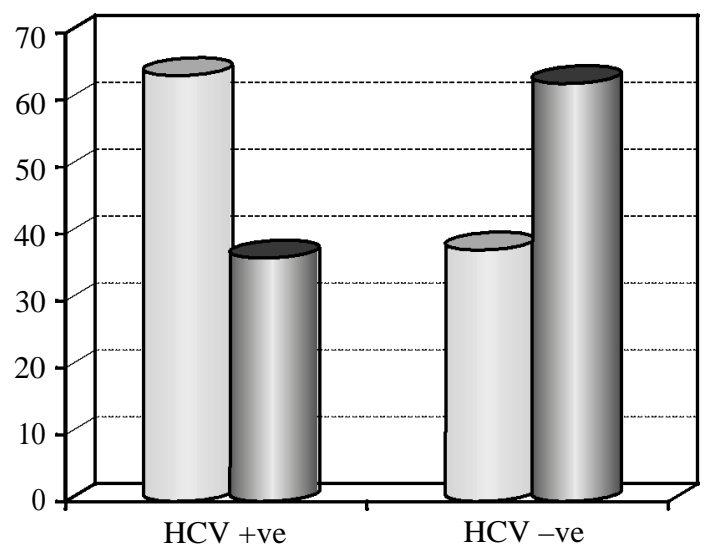

\section{Severe $\square$ Moderate}

Fig. (2): Percent of moderate and severe TBI in $\mathrm{HCV}+\mathrm{ve}$ and $\mathrm{HCV}$-ve patients.
Table (4): ICU stay.

\begin{tabular}{cccccc}
\hline & Mean & $\begin{array}{c}\text { Standard } \\
\text { deviation }\end{array}$ & Median Minimum & Maximum \\
\hline ICU stay & 9.33 & 9.18 & 6.50 & 2.00 & 42.00 \\
\hline
\end{tabular}

Table (5): Ventilator days.

\begin{tabular}{lccccc}
\hline & Mean & $\begin{array}{c}\text { Standard } \\
\text { deviation }\end{array}$ & Median & Minimum & Maximum \\
\hline $\begin{array}{l}\text { Ventilator } \\
\text { days }\end{array}$ & 13 & 12.11 & 9 & 1 & 42.00 \\
\hline
\end{tabular}

Table (6): Case deterioration, resurgery, mortality and ventilator requirements in both groups.

\begin{tabular}{lccccc}
\hline & \multicolumn{2}{c}{$\mathrm{HCV}+\mathrm{ve}$} & \multicolumn{2}{c}{$\mathrm{HCV}-\mathrm{ve}$} & $\begin{array}{c}p- \\
\text { value }\end{array}$ \\
\cline { 2 - 5 } & Count & $\%$ & Count & $\%$ & \\
\hline $\begin{array}{l}\text { Case deterioration } \\
\text { after admission: }\end{array}$ & & & & & \\
$\quad$ Yes & 5 & 45.5 & 25 & 22.9 & 0.140 \\
$\quad$ No & 6 & 54.5 & 84 & 77.1 & \\
$\quad$ Resurgery: & & & & & \\
$\quad$ Yes & 1 & 9.1 & 4 & 3.7 & 0.387 \\
$\quad$ No & 10 & 90.9 & 105 & 96.3 & \\
$\quad$ Mortality: & & & & & \\
$\quad$ Yes & 7 & 63.6 & 21 & 19.3 & 0.003 \\
$\quad$ No & 4 & 36.4 & 88 & 80.7 & \\
$\quad$ Ventilator & & & & & \\
requirements: & & & & & \\
$\quad$ Yes & 8 & 72.7 & 44 & 40.4 & 0.055 \\
$\quad$ No & 3 & 27.3 & 65 & 59.6 & \\
\hline
\end{tabular}

Table (7): ICU stay, ventilator days, GOS in both groups.

\begin{tabular}{lccccccccccc}
\hline & \multicolumn{4}{c}{ HCV +ve } & \multicolumn{3}{c}{ HCV -ve } & $p$ - \\
\cline { 2 - 12 } & Mean & SD & Median & Minimum & Maximum & Mean & SD & Median & Minimum Maximum & value \\
\hline ICU stay & 8.73 & 4.78 & 10.00 & 2.00 & 15.00 & 9.39 & 9.52 & 6.00 & 2.00 & 42.00 & 0.422 \\
Ventilator days & 8.69 & 4.12 & 10.00 & 4.00 & 15.00 & 12.51 & 12.30 & 10.00 & 1.00 & 42.00 & 0.052 \\
GOS & 2.36 & 1.91 & 1.00 & 1.00 & 5.00 & 3.81 & 1.59 & 5.00 & 1.00 & 5.00 & 0.012 \\
\hline
\end{tabular}

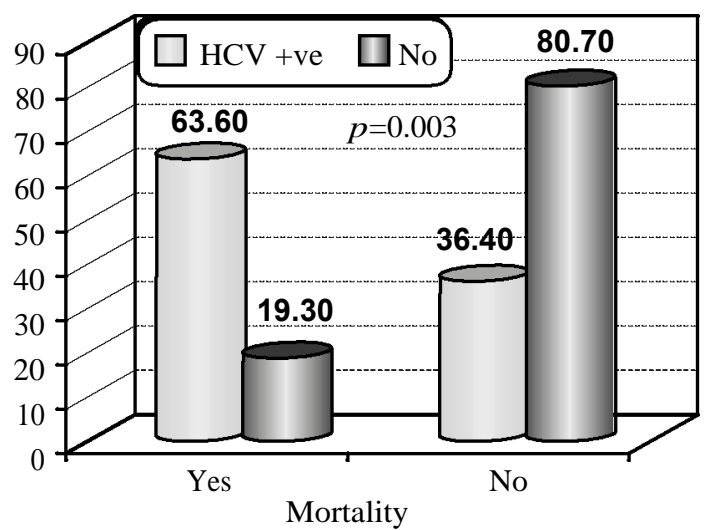

Fig. (3): Mortality in HCV +ve (blue bars) patients and HCV -ve patients (red bars).

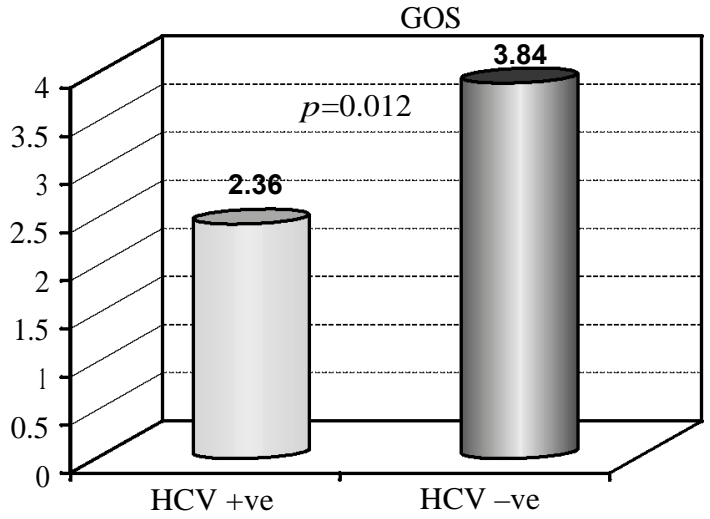

Fig. (4): GOS in HCV +ve (blue bar) and HCV -ve patients (red bar). 


\section{Confounders:}

We thought that confounding variables for this study were age and GCS on admission. In order to evaluate their effect on outcome of $\mathrm{HCV}+\mathrm{ve}$ patients with TBI, we performed multiple logistic regressions (Tables 8,9,10).

GCS on admission showed significant effect on mortality ( $p=0.001)$. However, after its adjustment using logistic regression, $\mathrm{HCV}+$ ve patients still showed significantly higher mortality rates than HCV negative patients $(p=0.025)$.

When assessing other outcomes as ventilator requirements, case deterioration after admission and length of ICU stay, GCS showed significant effect on outcome while HCV +ve patients showed no significant effect.

Table (8): Logistic regression between mortality as dependent variable and $\mathrm{HCV}$ as independent predictor after adjusting for confounders (age and Glasgow coma scale on admission).

\begin{tabular}{|c|c|c|c|c|}
\hline & \multirow{2}{*}{$p$-value } & \multirow{2}{*}{ OR } & \multicolumn{2}{|c|}{ 95\% C.I. } \\
\hline & & & Lower & Upper \\
\hline \multicolumn{5}{|c|}{ Mortality: } \\
\hline HCV & .25 & 18.935 & 1.447 & 247.760 \\
\hline Age & .793 & .994 & .947 & 1.043 \\
\hline GCS & $<0.001$ & .418 & .293 & .596 \\
\hline
\end{tabular}

Table (9): Logistic regression between ventilator requirement as dependent variable and $\mathrm{HCV}$ as independent predictor after adjusting for confounders (age and Glasgow coma scale on admission).

\begin{tabular}{lllll}
\hline & & & \multicolumn{2}{c}{$95 \%$ C.I. } \\
\cline { 4 - 5 } & $p$-value & OR & Lower & Upper \\
\hline Ventilator & & & & \\
requirement: & & & & \\
HCV & .109 & 160.538 & .321 & 80257.856 \\
Age & .782 & 1.009 & .948 & 1.073 \\
GCS & $<0.001$ & .092 & .027 & .314 \\
\hline
\end{tabular}

Table (10): Logistic regression between case deterioration after admission as dependent variable and $\mathrm{HCV}$ as independent predictor after adjusting for confounders (age and Glasgow coma scale on admission).

\begin{tabular}{lllll}
\hline & & & \multicolumn{2}{c}{$95 \%$ C.I. } \\
\cline { 4 - 5 } & $p$-value & OR & Lower & Upper \\
\hline Case & & & & \\
deterioration: & & & & \\
HCV & .738 & 1.345 & .237 & 7.615 \\
Age & .333 & 1.018 & .981 & 1.057 \\
GCS & $<0.001$ & .573 & .457 & .718 \\
\hline
\end{tabular}

Table (11): Linear regression between length of ICU stay as dependent variable and HCV as independent predictor after adjusting for confounders (age and Glasgow coma scale on admission).

\begin{tabular}{lll}
\hline & & $p$-value \\
\hline \multirow{4}{*}{ ICU stay } & Age & .992 \\
& GCS & $<0.001$ \\
& HCV +ve & .327 \\
\hline
\end{tabular}

\section{Discussion}

The aim of our study was to evaluate impact of $\mathrm{HCV}$ on prognosis of moderate and severe TBI patients in Egypt regarding mortality, length of ICU stay, ventilator requirements and their outcome. Our study included 120 moderate and severe head trauma patients admitted to the Cairo University Hospitals during the period between February 2016 and January 2017. Screening for HCV antibodies with ELISA technique was done to detect $\mathrm{HCV}+$ ve patients.

Out of the 120 patients included; only 11 patients $(9.2 \%)$ were $\mathrm{HCV}$ +ve while 109 patients (90.8\%) were found negative for HCV antibody.

The lower prevalence of HCV +ve antibodies in our studied patients than that of the general Egyptian population (15-20\%) can be attributed to the relatively young age of trauma patients as the median age of our studied patients was 26 years while prevalence of $\mathrm{HCV}$ is higher in older age groups (mean age of $\mathrm{HCV}+\mathrm{ve}$ patients in our study was 49.7).

In our study, Among the 120 TBI patients: 112 were males $(93.3 \%)$ and 8 were females $(6.7 \%)$. Out of the 112 males, $11(9.8 \%)$ were found HCV +ve and $101(90.2 \%)$ were found HCV -ve. All females included in the study were found $\mathrm{HCV}$ $-v e$. Among the HCV +ve patients; 5 were Child A $(45.5 \%)$ and 6 were Child B (54.5\%).

In our study, $72(60 \%)$ patients suffered from moderate TBI while $48(40 \%)$ patients suffered from severe TBI with overall median GCS of 8 . Of the HCV +ve group; 4 (36.4\%) had moderate TBI and 7(63.4\%) had severe TBI, while of the HCV -ve group; 68 (62.4\%) had moderate TBI and $41(37.6 \%)$ had severe TBI. Of all 120 TBI patients, 30 patients $(25 \%)$ deteriorated after admission while 90 patients (75\%) did not.

In our study, of all 120 TBI patients, 5 patients (4.2\%) had resurgery for evacuation of recollected hematoma or wound debridement, while 115 patients $(95.8 \%)$ didn't. 
In our study, Mean length of ICU stay in our 120 studied patients was found to be $9.3 \pm 9.18$ days, ranging from 2 to 42 days. Of all 120 TBI patients, 52 patients $(43.3 \%)$ required ventilation while 68 patients $(56.7 \%)$ didn't. Ventilator days ranged from 1 to 42 days with mean duration of $13 \pm 12.11$ days.

In our study, of all $120 \mathrm{TBI}$ patients, 28 patients (23.3\%) had mortality while 92 patients $(76.7 \%)$ didn't. There was significant difference between the two groups regarding mortality $(p=0.003)$ as we found that among the HCV +ve group; 7/11 patients $(63 \%)$ had mortality while among the $\mathrm{HCV}$ -ve group; only $21 / 109$ patients (19.3\%) had mortality.

In Lustenberger et al.'s study [14], a National Trauma Databank study over a 5-year period, including patients with isolated TBI who have liver cirrhosis and matching them with non cirrhotic, overall mean age was $50.8 \pm 22.6$, that in Cirrhotic patients was $55.0 \pm 11.8$ and in non cirrhotic patients was $51.7 \pm 26.2$. In our study, the overall mean age was $29.28 \pm 16.13$ years. Mean age was significantly higher among the HCV +ve patients $(49.73 \pm 12.11)$ than among the HCV -ve patients $(27.21 \pm 15.04)$. In both studies, mean age of Hepatic patients was higher than that of non hepatic patients. However, in our study, this difference was much more significant $(p<0.001)$, which can be the cause of higher mortality rates in $\mathrm{HCV}+$ ve patients compared with other studies as will be discussed later.

In Lustenberger et al. [14], male gender was prevalent $78.0 \%(110 / 141)$ which is close to our study $93.3 \%(112 / 120)$. This can be attributed to the higher incidence of male gender in trauma patients.

In Lustenberger et al. [14], severe TBI represented overall 21.3\% (30/141), in Cirrhotic patients: $23.4 \%$ (11/47) and in non cirrhotic patients: $20.2 \%$ (19/94). Moderate TBI represented overall 7.8\% (11/141), in Cirrhotic patients: 6.4\% (3/47), and in non cirrhotic patients: $8.5 \%$ (8/94).

In our study, severe TBI represented overall 48/120 (40\%), in HCV +ve patients: 7/11 (63\%) and in HCV -ve group: 41/109 (37.6\%). Moderate TBI represented overall $72 / 120(60 \%)$, in the HCV +ve group: 4/11 (36.4\%) while in the HCV -ve group: 68/109 (62.4\%). The higher incidence of severe TBI in HCV +ve patients in our study can be the cause of higher mortality rate in this group compared with other studies as will be discussed later.

\section{Outcome assessment:}

Our study results were close to Lustenberger et al. [14] regarding mortality but not regarding length of ICU stay and ventilator days.

In Lustenberger et al. [8], overall mortality was 23.4\% (33/141), in cirrhotic patients: $34 \%$ (16/47) and in non cirrhotic patients: $18.1 \%(17 / 94)$ $(p=0.035)$. In our study, overall mortality was 28 patients $(23.3 \%)$ which is almost the same. However, mortality among HCV +ve patients was much higher: $7 / 11$ patients $(63 \%)$ compared with the HCV -ve patients: $21 / 109$ patients $(19.3 \%)$ $(p=0.003)$. This higher mortality rate of $\mathrm{HCV}+\mathrm{ve}$ patients in our study compared to other studies can be attributed to higher age and lower GCS on admission in these patients as discussed earlier. That's why we performed multiple logistic regressions (Tables 14,15,16). GCS on admission showed significant effect on mortality $(p=0.001)$. However, after its adjustment using logistic regression, $\mathrm{HCV}$ +ve patients still showed significantly higher mortality rates than $\mathrm{HCV}-$ ve patients $(p=0.025)$.

In Lustenberger et al. [14], overall Length of ICU stay was 4.2 \pm 7.7 days, in Cirrhotic patients: $5.4 \pm 8.8$ and in non cirrhotic patients $3.7 \pm 7.0$ $(p=0.079)$. In our study, overall ICU stay was $9.3 \pm 9.18$ days, in $\mathrm{HCV}+$ ve patients: $8.73 \pm 4.78$ and in HCV -ve patients: 9.39 $\pm 9.52 .(p=0.422)$. This shorter length of ICU stay of HCV +ve patients compared to $\mathrm{HCV}$-ve patients in our study can be attributed to the higher mortality rate in this group in our studied patients compared to other studies.

Also in Lustenberger et al. [14], overall ventilator days were $2.3 \pm 6.4$ days, in Cirrhotic patients: $2.9 \pm 6.4$ and in non cirrhotic patients: $2.0 \pm 6.4$ $(p=0.001)$. In our study overall ventilator days were $13 \pm 12.11$ days, in HCV +ve patients: $8.69 \pm$ 4.12 and in HCV -ve patients: $12.51 \pm 12.31$ days.

In our study HCV +ve patients showed significantly lower GOS on admission than HCV -ve patients as we found that the mean GOS was $2.36 \pm 1.91$ in the former and $3.84 \pm 1.59$ in the latter group $(p=0.012)$.

When viewing our primary outcome (mortality) in other related studies, we found that:

In Cheng et al. [15] which is a retrospective study that investigated the 1-year mortality of patients who underwent brain surgery following traumatic brain injury (TBI) who also had liver cirrhosis using a nationwide database in Taiwan, they found that cirrhotic TBI patients who under- 
went brain surgery had higher 30-day mortality $(32.2 \%$ vs $19.4 \%)$.

In Chen et al. [11], a retrospective single-center study including all consecutive patients with liver cirrhosis who underwent brain surgery at Chang Gung Memorial Hospital, they found that out of 32 TBI patients who underwent surgeries, mortality occurred in 12 of them (37.5\%).

Several factors may have adversely affected outcome in the cohort of HCV + ve TBI patients. Traumatic brain injury is associated with a high incidence of coagulation disorders, conventionally attributed to the local and subsequent systemic release of tissue factor from the injured brain parenchyma. This tissue factor release results in an unregulated activation of the extrinsic coagulation pathway leading to a consumptive coagulopathy. In addition, cirrhotic patients may also frequently suffer an acquired coagulopathy characterized by thrombocytopenia, abnormal fibrinolysis, and a reduction in all clotting factors, except factor VIII and von Willebrand factor.

The combination of the two, cirrhosis and tissue factor-related coagulopathy, might expose cirrhotic patients who experience TBI to a high risk for progression of intracranial injuries and poor outcomes.

Cirrhosis-related complications may be associated with acquired thrombocytopenia and coagulopathy resulting from hypersplenism, impaired liver function with decreased fibrinogen and increased fibrinolysis, damaged systemic vessel walls and deficient platelet aggregation, the induction of hypertension, and activation of the clotting cascade.

Thus, in the clinical management of these patients, early identification, aggressive monitoring and treatment, and a careful selection of therapeutic interventions are required.

\section{Limitation and criticism:}

To the best of our knowledge this is the first prospective study focusing on the impact of $\mathrm{HCV}$ infection on outcome of TBI patients. However, there are several limitations to consider. We needed larger number of HCV +ve patients to be included in the study in order to get significant results about the difference between different Child-Pugh score patients, and to be properly matched with $\mathrm{HCV}$ -ve TBI patients regarding age and Glasgow coma scale on admission which significantly affected outcome, Also patients did not perform PCR (Polymerase Chain Reaction) to check whom are active and if virus titre was tolerated to outcome and finally there was little studies in the literature to compare our results with them.

However, the accuracy of data presented in the study has resulted in statistically sound results, which coincide with the published studies regarding its primary outcome (mortality).

\section{Conclusion:}

It is concluded that traumatic brain injury (TBI) in $\mathrm{HCV}+\mathrm{ve}$ patients is associated with significantly increased mortality rates and lower Glasgow outcome score (GOS) compared with HCV -ve patients. Unlike the published literature, our study showed no significant increase of length of ICU stay or ventilator requirements in these patients. Other significant prognostic indicators were age and Glasgow coma scale on admission.

Thus, in the clinical management of these patients, early identification, aggressive monitoring and treatment, and a careful selection of therapeutic interventions are required.

\section{Acknowledgment:}

We thank Prof Dr. Tamer Albaz professor of hepatology Faculty of Medicine, Cairo University for sharing his pearls of wisdom with us during the course of this research. We are also grateful to him for his comments on an earlier version of the manuscript, also any errors are our own and should not tarnish the reputation of him.

\section{References}

1- FAUL M., XU L., WALD M.M., et al.: Traumatic Brain Injury in the United States: National Estimates of Prevalence and Incidence, 2002-2006. Injury Prevention, 16: A268-A. PubMed PMID: WOS:0002840 77201145. Sep., 2010.

2- McGUIRE L.C., FAUL M., WALD M., et al.: Traumatic Brain Injury in Older Adults: Newly Released National Estimates, 50: 520-1. PubMed PMID: WOS:000286006 703727. Gerontologist, Oct., 2010.

3- MAAS A.I., STOCCHETTI N. and BULLOCK R.: Moderate and severe traumatic brain injury in adults, 7: 728741. Lancet Neurol., 2008.

4- MONTASER T. and HASSAN A.: Epidemiology of moderate and severe traumatic brain injury in Cairo University Hospital in 2010, 17 (Suppl. 2), P320. http://doi.org/ 10.1186/cc 12258. Critical Care, 2013.

5- STIVER, SHIRLEY and T. MANLEY, GEOFFREY: Prehospital management of traumatic brain injury, 25. E5. 10.3171/FOC.2008.25.10.E. Neurosurgical Focus, 2008.

6- GOWER E., ESTES C., BLACH S., RAZAVI-SHEARER $\mathrm{K}$. and RAZAVI H.: Global epidemiology and genotype distribution of the hepatitis $C$ virus infection, 61: S45S57. Journal of Hepatology, 2014. 
7- KANDEEL A., GENEDY M., EL-REFAI S., FUNK A.L., FONTANET A. and TALAAT M.: The prevalence of HCV infection in Egypt 2015: Implications for future policy on prevention and treatment, (3). doi:10.1111/liv. 13186. Liver Int., 2016.

8- CHRISTMAS A.B., WILSON A.K. and FRANKLIN G.A.: Cirrhosis and trauma: A deadly duo.,71 (12): 996-1000. PubMed PMID: 16447467. Am. Surg. Dec., 2005.

9- BAJAJ J.S., ANANTHAKRISHNAN A.N. and McGINLEY E.L.: Deleterious effect of cirrhosis on outcomes after motor vehicle crashes using the nationwide inpatient sample, 103 (7):1674-81. PubMed PMID: 18616657. Am. J. Gastroenterol., Jul., 2008.

10- TALVING P., LUSTENBERGER T. and OKOYE O.T.: The impact of liver cirrhosis on outcomes in trauma patients: A prospective study, 75 (4): 699-703. PubMed PMID: 24064886. J. Trauma Acute Care Surg. Oct., 2013.

11- CHEN C.C., HUANG Y.C. and YEH C.N.: Neurosurgical procedures in patients with liver cirrhosis: A review., 2352-2357. doi:10.4254/wjh.v7.i21.2352. PMID: 26413225; PMCID: PMC4577643. World Journal of Hepatology, Sep., 7 (21), 2015.

12- CHAN Y.H.: Biostatistics 201. Linear regression analysis, 45 (2): 55-61. Singapore Med. J., 2004.

13- CHAN Y.H.: Biostatistics 103. Qualitative Data-Tests of Independence, 44 (10): 498-503. Singapore Med. J., 2003.

14- LUSTENBERGER T., TALVING P., LAM L., INABA K., BRANCO B.C., PLURAD D. and DEMETRIADES D.: Liver cirrhosis and traumatic brain injury a fatal combination based on National Trauma Databank Analysis, 77: 311-314. Am. Surg., 2011.

15- CHENG C.-Y., HO C.-H. and WANG C.-C.: One-Year Mortality after Traumatic Brain Injury in Liver Cirrhosis Patients A Ten-Year Population-Based Study, 94(40), e1468. http://doi.org/10.1097/MD.000000000000 1468. Medicine, 2015.

\section{تقييه إصابة الهخ المتوسطة والشديلدة

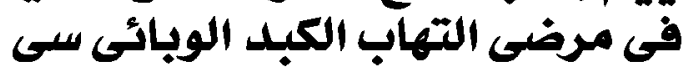

$$
\begin{aligned}
& \text { تعد إصابات الرأس من أهم أسباب العجز والوفاة بالعالم. كما يمثل مرض التليف الكبدى عاملاً مؤثراً لزيادة نسب العجز والوفاة بهؤلاء } \\
& \text { المرضى. ويعد أهم سبب اللتليف الكبدى فى مصر ومن أهم أسبابها بالعالم هو الإتهاب الكبدى الفيروسى (سىى). } \\
& \text { لذلك كان لابد من تقييم نتائج مرضى الإلتهاب الكبدى الفيروسى سى المتعرضين لإصابات الرأس المتوسطة والشديدة }
\end{aligned}
$$

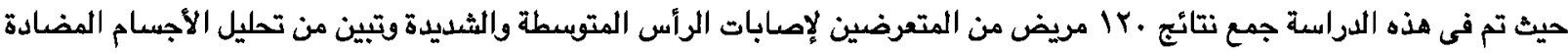

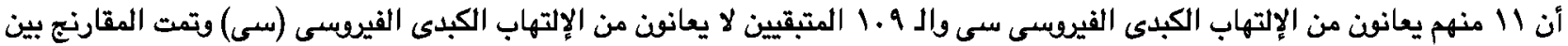

$$
\begin{aligned}
& \text { نسب الوفاة بين المجموعتين. } \\
& \text { وجدنا أن نسبة الوفاة بالمرضى الذين يعانون من الإلتهاب الكبدى الفيروسى (سى) المتعرضين لإصابات الرأس المتوسطة والثديدة أعلى } \\
& \text { كيراً ممن لا يعانف من الإلتهاب الكبدى الفيروسى (سىى). } \\
& \text { إستاداً إلى ذلك، فإنه من المهم التعرف المبكر على هؤلاء المرضى واخضاعهم لملاحظة دقيقة عن قرب ومتابعتهم عن كثب واختيار طرق } \\
& \text { العلاج المناسبة لهم. }
\end{aligned}
$$

